Volume 11 Number 1, January-March 2017: pp. 85-96 . Copyright (c) 2015-2016 FIAT JUSTISIA. Faculty of Law, Lampung University, Bandarlampung, Lampung, Indonesia. ISSN: 1978-5186 | e-ISSN: 2477-6238.

Open Access: http://jurnal.fh.unila.ac.id/index.php/fiat

Fiat Justisia is licensed under a Creative Commons Attribution 4.0 International License, which permits unrestricted use, distribution, and reproduction in any medium, provided the original work is properly cited.

\title{
TPP (Trans-Pacific Partnership) and Digital Copyright Infringement (Conflict Interest between Japan, USA, and Indonesia)
}

\author{
Bayu Sujadmiko \\ Kanazawa University, Japan \\ bayu.sujadmiko@fh.unila.ac.id
}

\begin{abstract}
Japan and the United States are sample countries, which have effectively control to reduce the number of illegal file sharing. They attempt to create a healthy Internet environment by promoting the Trans-Pacific Partnership (TPP). However, not all the members and its domestic parliaments agree with the whole provisions, specifically on Intellectual Property Chapter. Though, they keep strain to invite other nations to join the treaty. Indonesia agreed with the virtuous purposes of TPP, but it is too fast for Indonesia to ratify into domestic regulation. Indonesia is not ready yet to face the global market with low-potency. The article will show what the interest of both countries behind the TPP agreement is. It also describes how domestic copyright regulation touches illegal file sharing practices.
\end{abstract}

Keywords: TPP, illegal file sharing, enforcement

\section{A. Introduction}

Exchanging prohibited file via the web is currently reduced by only a small number of countries with productive control. To reinforce prohibited file exchanging, it is often to use technology. This study compared Japan and United States of America in making good cyberspace environment. An improvement made by Japan Copyright Law to support digital copyright which has not been taken by The United States of America and Indonesia affirms that private utilization of downloading is an illegal action. To find the trespasser and the illegal file sharer, Japanese cyber police and all parties associated with copyright have made a strategic improvement. 
Though society has been socialized to stop the prohibited downloading, the file sharer can even make a large amount of money for many years. Furthermore, the problem is not only digital piracy but also physical piracy which occurs widely in Indonesia. The improvement of Copyright Law in 2014 where Indonesia change international copyright regulation into national term did not manage to make a better condition for copyright practice and market. There are still many illegal contents can be freely downloaded in cyberspace and also a lot of open physical piracy markets.

Twelve countries across the Asia Pacific have associated to make an international agreement to support digital copyright as the TransPacific Partnership Agreement (TPP). ${ }^{1}$ There are still several unresolved issues especially copyright and internet issues, despite 20 chapters have been discussed after TPP negotiation runs for almost five years. ${ }^{2}$

TRIPS Agreement and international best practices are the basic standards which protection from TPP'S Intellectual Property includes any forms of intellectual property such as trade secrets, trademarks, industrial design, copyrights, patents, geographical indications. ${ }^{3}$ The commitment of technological protection measures and information on rights management as well as works protection, efficiency, phonograms includes songs, movies, books, and software are established in the copyright chapter. ${ }^{4}$ With exclusion and border, legal purpose and good digital environment should be balanced by all members as their liability. The system of copyright safe establishment and sustainability for Internet Service Provider (ISPs) prohibits any

\footnotetext{
${ }^{1}$ Inkyo Cheong, "Negotiation for the Trans-Pacific Partnership Agreement: Evaluation and Implications for East Asian Regionalism", 428 ADBI Working Paper Series, (2013), pp. 4-5.

2 Trans-Pacific Partnership Agreement (TPP): Intellectual Property Right Chapter, Draft Feb. 2011, Art. 15 (4), available at http://keepthewebopen.com/tpp (accessed March 16, 2015).

${ }^{3}$ Beside copyright, TPP rules; Paten and trademarks provides protections of brand names and other marks of those businesses and individuals, which used to differentiate their products in the marketplace. The protection of geographical indication also covered by certain transparency and safeguard process including through international, regional agreement and understanding on the relationship between trademarks and other commonly used terms. Additionally, the chapter rules pharmaceutical related facilitate innovation, generic medicine, public health and new pharmaceutical or agriculture chemical products, see also Lewis, Meredith Kolsky, The Trans-Pacific Partnership: New Paradigm or Wolf in Sheep's Clothing?. 34 B.C. Int'l \& Comp. L. Rev, (2011), 27

${ }^{4}$ Chapter 18 sections H, Trans-Pacific Partnership Agreement. 2015.
} 
parties to make trespassing activity by the monitoring system to make a safe harbors contingent.

It is finally agreed among TPP members for making big support systems which cover measures of provisional, procedures of both civil and criminal, cloning and copyright for commercial-brand, or any rights piracy. Commercial scale trespassing copyright such as copyright or IP trespassing with or without financial gain are examples of criminal acts where the nations need to give criminal punishment for. ${ }^{5}$ Financial gain means expecting value, such as single copyrighted content. This provision made to prevent cyber-theft misuse. $^{6}$

Japan and USA collaborated to give big support for punishment system and provisional measures in digital copyright trespassing. Freedom of digital, civil liberties and law of copyright are wished to be improved by the twelve counties. And the focus of TPP is to promote enlargement of economic, to get enough agreement for farmers and workers and to decrease any obstacles to the trade market.

Members have done classifying text and preparation for applying document supervision after TPP's closed negotiation. The draft for reinforcement of patent terms, medical patents, aggressive measure as digital copyright contents avoiding, criminal system and punishment for trade secret theft as cyber theft are the contents of intellectual property chapter which is one of the big issues in the agreement. There are two standpoints can be assessed as TPP response, as the first one, copyright holder, security companies, (DRM technology business) and Internet Service Provider (ISPs) companies which are supported by most parties government. Otherwise, since TPP is considered as the first agreement defines enforcing IPR as digital enforcing physical piracy, it becomes anxiety of commercial internet companies, bloggers, illegal website owner, and user.

\footnotetext{
${ }^{5}$ id, at Art 15 (1), see also Michael A. Carrier, supra note 36, at 25.

${ }^{6}$ Ibid., see also Press Release, Congressman Darrell Issa, Issa Releases the Trans Pacific Partnership Intellectual Property Rights Chapter on KeepTheWebOPEN.com (May 15, 2012) http://issa.house.gov/press-releases/2012/05/issa-releases-the-trans-pacific-partner shipintellectual-property-rights-chapter-on-keepthewebopencom/ (accessed March 16, 2015)
} 


\section{B. Analysis And Discussion}

\section{U.S. Proposal and TPP contradiction}

It can be beneficial for the United States of America in trade promotion and innovation along with scientific, technological and artistic share all over the regions through TPP ${ }^{7}$ since it can combine provision and U.S law to balance the protection. ${ }^{8}$ TPP can propose some aspects are best protection standards, States' exports and customers security towards IP cloning, physical piracy, and brand trespassing and also to protect creative and commercial contents by avoiding digital trade secret theft, digital piracy, and illegal file exchange. The agreement can propose the government for safe harbor establishment by business expanding and managing effective digital copyright trespass. It is not necessary for network content monitoring by ISPs but giving protection towards safe harbor misuse is required. ${ }^{9}$

Otherwise, TPP is not considered as NAFTA expansion models such as service of financial, e-commerce, technology, and intellectual property more than a new trade agreement model.

In conclusion, a domestic policy which firstly agreed by all members will change the provision. It refers to "Binding International Governance System" where TPP can support permanent limit between domestic and state policymaking. ${ }^{10}$ It considered TPP as SOPA and ACTA sustainability ISPs safe harbor established. President Obama, Congress, and USTR Michael Forman ${ }^{11}$ were challenged about this issue by sending a letter protest since, in their point of view, TPP negotiation which secretly held doesn't suit the value of US democratic. Subscriber service termination and blocking content can cause trespassing act. Therefore, it is their liability in network monitoring and taking a big effort for it. Since any contents of

\footnotetext{
7 USTR. IP chapter summary of TPP. available at https://medium.com/the-trans-pacificpartnership/intellectual-property-3479efdc7adf\#.41bgjvfkf (accessed December 3, 2015)

${ }^{8}$ Ibid.

${ }^{9}$ TPP Agreement, Chapter 18, Annex 18 E \& F.

${ }^{10}$ Ibid.

${ }^{11}$ Storm, Darlene. "Secret TPP agreement, SOPA on steroids, may be the end of the Internet as we know it", Computer World Web, November 18, 2013, available at http://www.computerworld.com/article/2475496/internet/secret-tpp-agreement--sopa-onsteroids--may-be-the-end-of-the-internet-as-we-know-it.html see also http://infojustice.org/wp-content/uploads/2013/11/Law-Professors-TPP-11142013.pdf, (accessed December 7, 2015).
} 
copyright pass through in cyberspace, disc, or devices, they are promoted to apply to impermanent copies.

Furthermore, the permission-based system will be formed to make any copyrighted work requires to get permitted by the copyright owner to download or view. Fines, punishment and civil remedy will be regulated for trespasser by members who defined by TPP. Criminal penalties enlargement is not the main focus of US as it is more flexible and adaptable for a minor action or non-financially violence. ${ }^{12}$

\section{TPP Means for Japan}

As addressing the TPP performance by Shinzo Abe, Japan Prime Minister, it is said: "TPP was a significant achievement not only for Japan but also for the future in the Asia Pacific Region." ${ }^{13}$ Making a free and fair economic region as progressive values distribution was seen as a visionary policy where the agreement is considered can decrease tariffs and covers forty percent of the economic field. ${ }^{14}$ Other nations as members use it as new standards. Trade improvement of members and facing the enlargement of China's economy becomes the aim of the deal. Off-duty and decreasing tariffs of countries are proposed for most goods and service in the operating system. Since becoming a new export superpower is the intention of Japanese government along with TPP Policy Paper, ${ }^{15}$ Japan will make a big growth for proactive export products and food in the industry with

\footnotetext{
${ }^{12}$ Not all the parties have fair use doctrine in their domestic law. Applying criminal penalties for private activities is complicated issue between law, legal culture, technology and user. TPP member who already use this provision under this law is Japan, see also Higgins, David. File Sharing and Downloading Laws in Japan, September 16, 2014, available at http://www.japanupdate.com/2014/09/file-sharing-and-downloading-laws-in-japan/ and BBC news, Japan Introduces Piracy Penalties for Illegal Downloads, October 1, 2012, available at http://www.bbc.com/news/technology-19767970, (accessed December 8, 2015)

13 Pollman, Mina. "What the TPP Means for Japan". Japan Times Web. October 8, 2015, available at http://thediplomat.com/2015/10/what-the-tpp-means-for-japan/, (accessed December 8, 2015).

${ }^{14} \mathrm{Ibid}$, see also wire report update of Shimbun, Asahi. "U.S., and 11 other Pacific Rim Countries Reach Sweeping Trade Deal". October 6, 2015. available at http://ajw.asahi.com/article/behind_news/politics/AJ201510060012, (accessed December 8, 2015).

15 Nagata, Kazuaki. (2015). "Japan Government Releases TPP Policy Paper in attempt to Quell Unease". Japan Times. November 25, 2015. available at http://www.japantimes.co.jp/ news/2015/11/25/business/japan-government-releases-tpp-policy-paper-attempt-quellunease/\#.VmZdXBOqqkp, (accessed December 8, 2015).
} 
written strategy by selling broadcast programming worth $¥ 20$ billion in 2018 and $¥ 1$ trillion of agricultural in 2020 . $^{16}$

There is a consideration of copyright law revision as the impact of digital copyright trespassing where the offender will be charged for copyright trespassing with or without a lawsuit from the owner of copyright and authorities will conduct the inquiry. ${ }^{17} \$ 13.8$ billion could be reached as the estimation of export marketplace ${ }^{18}$ includes copyrighted works, any contents, in the form of digital or physic in Japan. ${ }^{19}$ The revision of copyright law is well accepted and enforced by copyright association as an industry group. They are Japanese Society for Rights of Authors, Composers and Publishers (JASRAC); Association of Rights for Computer Software (ACCS); Recording Industry Association OF Japan (RIAJ); and Anti-Piracy Council to exploit File-sharing Software or Consortium against Copyright Infringement via File-sharing Software (CCIF).

Japan had conducted the pact conclusion by legislative session as TPP confirmation this November, and each member could sign and confirm the draft. January 2016 is the estimated time for final acceptance result from every member could be seen, as it took ninety days for the U.S. to review the draft and by January, there is no definite ratification from Japanese Diet. There will not be a big effect on people's interest because the government will refine the legitimated revision. ${ }^{20}$

As one of the members following TPP formulation about trespassing of digital copyright, Japan sued copyrighted contents download, where any organization or person committing music, movie, and software piracy were sued since October 2012 and police

\footnotetext{
${ }^{16}$ Ibid.

${ }^{17}$ Authorities can bring charges as well as allowing rights holders to seek statutory damages for infringements.

18 Jiji. "Japan to Strengthen Copyright Protections in Light of TPP", Japan Times Web, November 15, 2015, available at http://www.japantimes.co.jp/news/2015/11/15/business/ja pan-strengthen-copyright-protections-light-tpp/\#.Vk0zNBOqqkp, (accessed December 9, 2015).

${ }^{19}$ Manga is a Japanese cartoon, usually from the comic characters/actor.

${ }^{20}$ Ibid., see also Nikkei. With deal's details still a mystery, Japan parliament unlikely to meet, October 7, 2015, available at http://asia.nikkei.com/Politics-Economy/Policy-Politics/Withdeal-s-details-still-a-mystery-Japan-parliament-unlikely-to-meet, (accessed December 9, 2015).
} 
had found twenty-two cases in $2015 .{ }^{21}$ As stated by RIAJ, it managed to decrease forty percent of activities in prohibited file exchange and peer-to-peer after the support system introduction from legislation and in 2015 , it raised to 43,7 billion yen, about five percent increase in digital music sales as well as the higher subscription market every year. ${ }^{22}$ Addressing P2P and prohibited file exchange, ISPs becomes more aggressive by collaborating with the government to restrict internet activities such as giving limit capacity for internet quota, 10gb to $30 \mathrm{gb}$ for PC and any commercial internet and $5 \mathrm{gb}$ to $10 \mathrm{gb}$ for a smartphone. ${ }^{23}$ Every policy has a different way of monitoring internet activities, and it does not depend on instruction from officials. Response to any infringement depends on how big the material loss, only illegal content deletion, and warning or even calling the police.

TPP causes different impacts for different industries; banned tax and tariffs can see it. Due to the low cost for export to the U.S, cheap automotive spare part in Vietnam and also the lower production cost, automotive industries get big advantages. As the tariffs deletion, it influences the competition of import and local price, like Vietnam, they can employ foreign worker cheaper than local worker based on the law of strict labor. Another benefit is for business in drugs maker; technology giants industries could compete better as the growth of green technology to decrease global warming ${ }^{24}$ and local infrastructure after eight years of protection for new biotech drugs which cause high price in developing countries. ${ }^{25}$

\section{Indonesia; Standing between the two Threats}

There are pros and cons to joining TPP in Indonesia by a lot of parties after President Jokowi's declaration to President Obama in

\footnotetext{
21 ACCS, criminal case report 2014-2015, available at http://www2.accsjp.or.jp/fileshare/criminal/index.php, (accessed December 9, 2015)

22 RIAJ Year Book 2015. (2015). Statistic Trend, p. 1.

${ }^{23} \mathrm{http}: / /$ isp.oshietekun.net/, (accessed December 9, 2015)

${ }^{24}$ Chapter 18, TPP agreement (biotech drugs are expensive medicines produced in living cells).

${ }^{25}$ Rajeshi Naidu-Ghelani, TPP Trade Deal: Who are the Winners and Losers?, BBC News, October 6, 2015, available at http://www.bbc.com/news/business-34451423, (accessed December 10, 2015).
} 
joining TPP. ${ }^{26}$ It is necessary to consider positive and negative effects by joining the agreement. We can say it is beneficial for consumers in Indonesia as the biggest Southeast Asia economy with a quarter million population to get a lower price and various options with the best quality. Furthermore, it is good for producers to get linked directly to international production with easy access to get raw material with low price and having the prosperous price of sales. Otherwise, producers should prepare well for the challenge they may face, if not ready to compete; they will turn down.

Indonesia has to compete with Vietnam as a developing country joining TPP; we should be ready to get access product from developed countries such as the U.S. and Japan which may be lessened by Vietnam. As what had passed five years ago, when Vietnam was able to export textile to the U.S. with $300 \%$ increase while $100 \%$ for Indonesia. Another obstacle to joining TPP is intellectual property ruled strictly, investment enlargement and the way to protect it by TPP. It will not be good for developing countries when conflict solving is lined up with ISDS (Investor-State Dispute Settlement), and free distribution can threaten the medical side and local farmer. In the end, regulation in domestic should be enforced by each member to suit business interest, in particular for taxes and export-import, and as a result, national companies and private companies have the same right in operation.

\begin{tabular}{|c|c|c|c|c|c|c|c|c|c|c|c|c|}
\hline $\begin{array}{c}\text { Intellectual } \\
\text { Property } \\
\text { Chapter } \\
\end{array}$ & $\begin{array}{c}\text { Austra } \\
\text { lia }\end{array}$ & $\mathbf{N Z}$ & US & Peru & $\begin{array}{c}\text { Chi } \\
\text { le }\end{array}$ & $\begin{array}{c}\text { Mex } \\
\text { co }\end{array}$ & $\begin{array}{c}\text { Cans } \\
\text { da }\end{array}$ & $\begin{array}{c}\text { Singa } \\
\text { pore }\end{array}$ & $\begin{array}{c}\text { Bru } \\
\text { nei }\end{array}$ & $\begin{array}{c}\text { Malay } \\
\text { sia }\end{array}$ & $\begin{array}{l}\text { Viet } \\
\text { nam }\end{array}$ & Japan \\
\hline $\begin{array}{l}\text { Patents: } \\
\text { Patentability } \\
\text { criteria }\end{array}$ & A & $\mathrm{R}$ & A & A & $\mathrm{R}$ & $\mathrm{R}$ & $\mathrm{R}$ & $\mathrm{R}$ & $\mathrm{R}$ & $\mathrm{R}$ & $\mathrm{R}$ & $\mathrm{R} / \mathrm{P}$ \\
\hline $\begin{array}{l}\text { Patents: } \\
\text { Supplementary } \\
\text { protection }\end{array}$ & $\mathrm{R}$ & $\mathrm{R}$ & A & $\mathrm{R}$ & $\mathrm{R}$ & $\mathrm{R}$ & $\mathrm{R}$ & $\mathrm{R}$ & $\mathrm{R}$ & $\mathrm{R}$ & $\mathrm{R}$ & $\mathrm{R}$ \\
\hline \begin{tabular}{|lr} 
Patents: & Extend \\
Protection & to \\
new & uses \\
(plants, & animals,
\end{tabular} & $\mathrm{R}$ & $\mathrm{R}$ & A & $\mathrm{R}$ & $\mathrm{R}$ & $\mathrm{R}$ & $\mathrm{R}$ & A & $\mathrm{R}$ & $\mathrm{R}$ & $\mathrm{R}$ & $\mathrm{R} / \mathrm{P}$ \\
\hline
\end{tabular}

\footnotetext{
${ }^{26}$ President of Indonesia, Joko Widodo was meeting with the US President, Barrack Obama at White House, available at http://www.theguardian.com/world/2015/oct/27/indonesia-willjoin-trans-pacific-partnership-jokowi-tells-obama, (accessed December 10, 2015)
} 


\begin{tabular}{|c|c|c|c|c|c|c|c|c|c|c|c|c|}
\hline \begin{tabular}{|l} 
surgical \\
procedures)
\end{tabular} & & & & & & & & & & & & \\
\hline $\begin{array}{l}\text { Pharmaceuticals: } \\
\text { linkage }\end{array}$ & $\mathrm{R}$ & $\mathrm{R}$ & A & $\mathrm{R}$ & $\mathrm{R}$ & $\mathrm{R}$ & $\mathrm{R}$ & $\mathrm{R}$ & $\mathrm{R}$ & $\mathrm{R}$ & $\mathrm{R}$ & $\mathrm{R}$ \\
\hline $\begin{array}{l}\text { Pharmaceuticals: } \\
\text { Data protection }\end{array}$ & $\mathrm{R}$ & $\mathrm{R}$ & A & $\mathrm{R}$ & $\mathrm{R}$ & $\mathrm{R}$ & $\mathrm{R}$ & $\mathrm{R}$ & $\mathrm{R}$ & $\mathrm{R}$ & $\mathrm{R}$ & $\mathrm{R}$ \\
\hline Copyright: TPM & A & $\mathrm{R} / \mathrm{P}$ & A & $\mathrm{A}$ & $\mathrm{R}$ & $\mathrm{A}$ & $\mathrm{R} / \mathrm{P}$ & $\mathrm{A}$ & $\mathrm{R}$ & $\mathrm{R}$ & $\mathrm{R}$ & $\mathrm{R}$ \\
\hline $\begin{array}{l}\text { Copyright: } \text { Term } \\
\text { of } \quad \text { protection } \\
\text { (US proposal) }\end{array}$ & $\mathrm{R}$ & $\mathrm{R}$ & A & $\mathrm{R}$ & $\mathrm{R}$ & $\mathrm{R}$ & $\mathrm{R}$ & $\mathrm{R}$ & $\mathrm{R}$ & $\mathrm{R}$ & $\mathrm{R}$ & $\mathrm{R}$ \\
\hline $\begin{array}{l}\text { Copyright: } \\
\text { Parallel } \\
\text { important } \\
\end{array}$ & $\mathrm{R}$ & $\mathrm{R}$ & A & $\mathrm{R}$ & $\mathrm{R}$ & $\mathrm{R}$ & $\mathrm{R}$ & $\mathrm{R}$ & $\mathrm{R}$ & $\mathrm{R}$ & $\mathrm{R}$ & $\mathrm{R}$ \\
\hline $\begin{array}{l}\text { Copyright: ISPs } \\
\text { (CL proposal) } \\
\end{array}$ & $\mathrm{R}$ & A & $\mathrm{R}$ & A & A & A & A & A & A & A & A & $\mathrm{R} / \mathrm{P}$ \\
\hline \begin{tabular}{|l|} 
Observations: \\
New elements of \\
Penal System: \\
Establishment of \\
criminal \\
offenses for \\
unintentional \\
infringements of \\
copyright, \\
related rights, \\
and trademarks \\
QQ.H.7.3) \\
\end{tabular} & $\mathrm{R}$ & $\mathrm{R}$ & A & $\mathrm{R}$ & $\mathrm{R}$ & $\mathrm{R}$ & $\mathrm{R}$ & $\mathrm{R}$ & $\mathrm{R}$ & $\mathrm{R}$ & $\mathrm{R}$ & $\mathrm{R}$ \\
\hline $\begin{array}{|lr|}\text { Observations: } \\
\text { New elements of } \\
\text { criminal code: } \\
\text { Obligations } \\
\text { establish } \\
\text { criminal } \\
\text { penalties } \\
\text { fines } \\
\text { recordings } \\
\text { public } r \\
\text { (camcording) } \\
\text { (QQ.H.7.5) } \\
\end{array}$ & A & $\mathrm{R}$ & $\mathrm{R}$ & $\mathrm{R}$ & $\mathrm{R}$ & $\mathrm{R}$ & A & $\mathrm{R}$ & $\mathrm{R}$ & A & $\mathrm{R}$ & $\mathrm{R}$ \\
\hline $\begin{array}{l}\text { The inclusion of } \\
\text { agreements that } \\
\text { parties should } \\
\text { ratify ry and } \\
\text { implement }\end{array}$ & A & $\mathrm{R}$ & A & $\mathrm{R}$ & $\mathrm{R}$ & $\mathrm{R}$ & $\mathrm{R}$ & $\mathrm{R} / \mathrm{P}$ & $\mathrm{R}$ & $\mathrm{R}$ & $\mathrm{R}$ & $\mathrm{R}$ \\
\hline $\begin{array}{l}\text { National } \\
\text { treatment: }\end{array}$ & $\mathrm{R}$ & A & $\mathrm{R}$ & A & A & $\mathrm{R} / \mathrm{P}$ & $\mathrm{R} / \mathrm{P}$ & A & A & A & A & A \\
\hline
\end{tabular}


maintain TRIPS

- A: Accept, R: Reject, R/P: Reserved Position.

- TPP Country Positions (6 November 2013)

Source: United States Trade Representative (USTR)

\section{Conclusion}

At the end of 2015, 12 countries agreed to sign the TPP agreement. Chapter 18 ruled about intellectual property, term, and its practices. A breakthrough by TPP in digital copyright enforcement contains the draft for reinforcement of patent terms, medical patents, aggressive measure as digital copyright contents avoiding, criminal system and punishment for trade secret theft as cyber thefare the contents of intellectual property chapter which is one of the big issues in the agreement. In Japan, any organization or person committing music, movie, and software piracy were sued since October 2012 and police had found twenty-two cases in 2015. Criminal penalties enlargement is not the main focus of US as it is more flexible and adaptable for a minor action or non-financially violence. There are pros and cons to joining TPP in Indonesia by a lot of parties. We can say it is beneficial for consumers in Indonesia as the biggest Southeast Asia economy with a quarter million population. Otherwise, producers should prepare well for the challenge they may face, if not ready to compete; they will turn down, and there will be unemployment increase. There are also interventions from TPP in criminal punishment legalization for prohibited digital copyright trespassing, and TPP also has the right to block any suspected contents. Asian Pacific liberalization seems not suitable for Indonesia in many aspects like economic circumstances, politic, law, and social culture. To follow the intention of joining TPP, Indonesia has to give big concerns to economic facilities, decreasing poverty, education and also law enforcement. The government would slowly enforce good socialization and penalties after the change of Indonesia Copyright Law 2014. An avoidance effect for other society and trespassing will occur caused by the steps. Though it can reduce digital piracy by websites blocking with copyright trespassing activities, there are no cases comes to the court which sued by some website owner and users. 


\section{A. Book}

\section{Bibliography}

Chapter 18 sections H, Trans-Pacific Partnership Agreement, 2015.

Chapter 18, TPP agreement (biotech drugs are expensive medicines produced in living cells).

Cheong, Inkyo. (2013). "Negotiation for the Trans-Pacific Partnership Agreement: Evaluation and Implications for East Asian Regionalism." 428 ADBI Working Paper Series, July 2013

Lewis, Meredith Kolsky. (2011). The Trans-Pacific Partnership: New Paradigm or Wolf in Sheep's Clothing?, 34 B.C. Int'l \& Comp. L. Rev. 27.

Mina Pollman, supra note 15.

RIAJ Year Book 2015, Statistic Trend, at 1.

TPP Agreement, Chapter 18, Annex 18 E \& F.

\section{B. World Wide Web}

http://www.bbc.com/news/business-34451423

http://asia.nikkei.com/Politics-Economy/Policy-Politics/With-deal-s-detailsstill-a-mystery-Japan-parliament-unlikely-to-meet

http://www2.accsjp.or.jp/fileshare/criminal/index.php

http://www.computerworld.com/article/2475496/internet/secret-tpp-

agreement--sopa-on-steroids--may-be-the-end-of-the-internet-as-weknow-it.html

http://www.bbc.com/news/technology-19767970

http://ajw.asahi.com/article/behind_news/politics/AJ201510060012

https://medium.com/the-trans-pacific-partnership/intellectual-property-

3479 efdc7adf\#.41bgjvfkf

http://keepthewebopen.com/tpp

http://issa.house.gov/press-releases/2012/05/issa-releases-the-trans-pacific-

partnership-intellectual-property-rights-chapter-on-

keepthewebopencom/

http://leg.wa.gov/JointCommittees/LOCTP/Documents/2012Nov14/TPP\%2

OPresentation.pdf

http://infojustice.org/wp-content/uploads/2013/11/Law-Professors-TPP-

11142013.pdf

http://www.michael geist.ca/2013/11/tpp-leak-isp-liability/

http://thediplomat.com/2015/10/what-the-tpp-means-for-japan/

http://www.theguardian.com/world/2015/oct/27/indonesia-will-join-trans-

pacific-partnership-jokowi-tells-obama

http://www.japantimes.co.jp/news/2015/11/15/business/ja pan-strengthen-

copyright-protections-light-tpp/\#.Vk0zNBOqqkp 
http://www.japantimes.co.jp/ news/2015/11/25/business/japan-governmentreleases-tpp-policy-paper-attempt-quell-unease/\#.VmZdXBOqqkp

http://isp.oshietekun.net/, (last visited December 9, 2015) 